\title{
PESOUISA PERFIL DA ENFERMAGEM INSTRUMENTO DE DEFESA DA PROFISSÃO
}

\section{LEVANTAMENTO DE RECURSOS E NECESSIDADES DE ENFERMAGEM- 1956/1958}

A Associação Brasileira de Enfermagem com apoio das fundações W. K. Kellogg e Rockfeller, ambas dos Estados Unidos e participação da OPAS, em meados da década de cinquenta, realizou o Levantamento de Recursos e Necessidades em Enfermagem no Brasil. A coleta de dados ocorreu ainda em 1956 e o relatório final foi apresentado em 1958 em evento próprio de abrangência internacional, na cidade de Salvador.

O relatório final, mimeografado teve circulação ${ }^{(1)}$ restrita, porém seu conteúdo foi amplamente divulgado entre os profissionais de enfermagem à época. O documento era amplo e se constituía de cinco partes: Enfermeiros em atividade e inativos; Enfermagem Hospitalar; Enfermagem em Saúde Pública; Escolas e Cursos de Auxiliar de Enfermagem e Escolas de Enfermagem.

A publicação em um livro seria divulgada somente em 1980. valendo muito mais como um registro histórico. No entanto, a competência para realizar pesquisas ficou consolidada, já que o estudo envolveu grandes números, amostragens e ocorreu em todo o território nacional( ${ }^{(1)}$.

\section{O EXERCÍCIO DA ENFERMAGEM NAS INSTITUIÇÕES DE SAÚDE DO BRASIL 1982/1983}

A partir de 1982 já realizávamos um segundo levantamento, resultado de parceria entre Cofen/ Aben. E estávamos já em um cenário bastante modificado, cujo o perfil da enfermagem carecia de maior visibilidade.

$\mathrm{Na}$ década de 1980, entre outras mudanças na profissão, havíamos experimentado um acréscimo de escolas, que 1956 eram de 33 unidades, somente. O número de egressos havia aumentado significativamente, a pós-graduação sofreu um implemento, com a introdução do mestrado e do doutorado. De modo que o cenário estava a demandar o conhecimento de nossa realidade como profissão. Motivo que levou as organizações de enfermagem (Cofen/Aben) a realizarem a pesquisa: O Exercício da Enfermagem nas Instituições de Saúde do Brasil, cuja divulgação se deu em dois volumes - Força de Trabalho de Enfermagem (vol I) e Enfermagem no Contexto Institucional - vol. II .

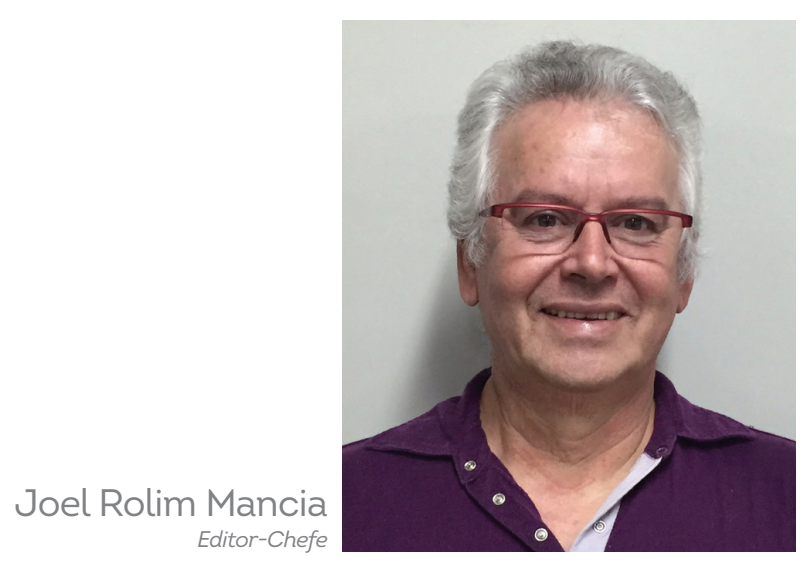

Assim, com os resultados deste estudo foi possivel realizar uma crítica da profissão, em um momento de efervescência política do país, os enfermeiros com essas informações foram capazes de organizar suas reivindicações com base em dados reais e atuais. Tendo então, a oportunidade de discutir melhor saúde, educação e condições laborais da enfermagem brasileira.

\section{PERFIL DA ENFERMAGEM BRASILEIRA- 2010/2015}

Em 2010 o Sistema Cofen/ Conselhos Regionais iniciaram em pareceria com o a Fiocruz a Pesquisa: Perfil da Enfermagem que era uma demanda já de longa data solicitada pela comunidade de enfermagem para a atualização de informações sobre a profissão no Brasil.

Este ano, maio de 2015 o resultado deste empreendimento foi apresentado à sociedade brasileira. Se constitui de uma quantidade de dados e informações, que somente em tabelas beiram as vinte mil e suas avaliações serão de grande valor para a profissão.

O resultado desta pesquisa é patrimônio dos profissionais de enfermagem, suas informações devem ser usadas amplamente pelos enfermeiros, técnicos e auxiliares de enfermagem. Suas informações são poderosas ferramentas para defesa da profissão e para seu empoderamento. Desde este entendimento apresentamos uma síntese da pesquisa, seus resultados seus, seus método para que a categoria possa usufruir deste produto como um guia oferecido pala revista oficial do Cofen.

${ }^{1}$ Mancia JR. Revista Brasileira de Enfermagem e seu papel na consolidação profissional [ tese ]. Universidade Federal de Santa Catarina;2007 